\title{
Transfusion Safety: Lessons Learned In Ibero-America And Considerations For Their Global Applicability
}

This article was published in the following Dove Press journal: International Journal of Clinical Transfusion Medicine

Jose Ramiro Cruz

Independent Consultant, Ashburn, VA, USA
Correspondence: Jose Ramiro Cruz Independent Consultant, 44408 Maltese Falcon Square, Ashburn, VA 20147, USA $\mathrm{Tel}+\mathrm{I} 7037290875$

Email jcruz62004@aol.com

\begin{abstract}
The safety of blood used for transfusions has historically been the main focus of the international health community. In the Americas, during the first decade of the 21 st Century, the attention switched to the patients who need transfusions and to the individuals who donate blood, that is, to transfusion safety. Timely and universal access to blood components implied adequate availability to sufficient blood components by patients who require transfusions in every hospital of every country. Clinical conditions and local non-medical factors influence decisions to admit and transfuse ill individuals. Locally-developed pertinent transfusion guidelines contribute to better estimate blood needs. Replacement blood donation hinders access to blood stocked in the hospitals blood banks and results in excessive component expiry and financial losses. Focusing on patient transfusion needs and on patient outcomes permits implementing national blood collection, processing and distribution, in consonance with the national health system. Analyses of general health conditions, by using the national Human Health Indexes, and the operational characteristics of blood services, by using the blood center density index, permit identification of locally pertinent interventions to improve transfusion safety. For this article, the analytical approaches used in IberoAmerica were applied to blood data from South-East Asian and African countries. Data collection and validation were identified as priorities for Asian countries. Estimating blood component requirements at the local level and adjusting blood collection, processing and distribution systems are important in Africa.
\end{abstract}

Keywords: blood safety, transfusion safety, blood donors, Human Health Index, Ibero-America

\section{Introduction}

The international health community has historically focused on reducing the infectious potential of blood for transfusions, that is, on blood safety. The first World Health Assembly (WHA) resolution on blood services, adopted in 1975, sought to curtail commercial blood collection and plasmapheresis in developing countries. The concerns of the WHA were the possible negative consequences of such activities for donors' health and for the safety of the resulting products. ${ }^{1,2}$ The 1975 resolution urged countries to instead promote blood services based on voluntary blood donation (VBD) and to protect the health of both blood donors and recipients. It was not until 1987 that the WHA discussed blood safety issues again, as part of the global strategy for AIDS prevention and control, ${ }^{3}$ approach that persisted within the World Health Organization (WHO) for two decades. ${ }^{4-6}$ The strategy for AIDS control laid the groundwork for the Global Safe Blood Initiative and provided the framework for initial actions to strengthen blood services by the 
WHO African Region ${ }^{7,8}$ and the Pan American Health Organization $^{9}$ (PAHO). During the first decade of the 21 st century, the WHA established a global plan for universal access to safe blood $^{10}$ with five components: a) development of nationally coordinated blood transfusion services, b) exclusive collection of blood from VBD, c) quality-assured laboratory testing, d) reduction of inappropriate transfusions, and e) implementation of quality blood collection and distribution systems.

In the Americas, by contrast, the First Pan American Conference on Blood Safety, held in 2003, developed an innovative plan to improve transfusion safety in the Region by $2010^{11}$ through: a) proper collection and preparation of sufficient blood components, b) timely access to blood components for patients, c) highest level of safety for blood products, d) appropriate transfusion practices, and e) efficient use of national resources. The strategies were: a) planning and management of the national blood network system, based on local needs b) promotion of VBD, through userfriendly blood collection services, c) quality assurance based on locally pertinent standards, and d) appropriate use of blood and blood components based on hospital-adapted transfusion guidelines. This article reviews lessons learned from the implementation of the Regional Plan for Transfusion Safety in Ibero-American countries and provides insights on how those lessons may be applicable in other regions of the world. The article takes as points of departure the following key concepts:

Global blood safety is not a measure of the risk of transmission of infectious agents through transfusion, but actually the goal of attaining the safest possible blood for every patient in every country of the world. To attain it, blood services are expected to collect blood from voluntary altruistic donors only, to carry out universal, pertinent and precise laboratory blood testing, and to protect blood components from contamination during their preparation and storage. Local surveillance of transfusion-transmissible infections (TTI), training of blood service staff, national oversight by health authorities and collaboration among stake holders are considered basic in the quest for global blood safety. ${ }^{12}$

VBD is that which is made with the purpose of contributing to the national sufficiency and general timely access to blood, without the intention of benefiting a specific patient. Voluntary donors do not profit by collecting either money or other material benefits. ${ }^{13}$

Replacement blood donation (RBD) is that which is made on behalf of a specific patient in response to a hospital requirement and prior to that patient being admitted, treated or discharged by the hospital. The patients or their family members are responsible for recruiting replacement donors. ${ }^{14}$

Transfusion safety is the expression of the pursuit of global blood safety in a given population while ensuring the protection of both the individuals who donate blood and those who receive it, and also making efficient use of local resources. Maximum transfusion safety can be achieved when ethical principles, locally pertinent clinical guidelines, and quality assurance measures are applied. ${ }^{15}$

\section{Country Data}

The 2016 WHO Global Status Report on Blood Safety and Availability ${ }^{16}$ was used as the source of all country data for 2013. This publication contains information collected from 178 countries as part of the Global Data Base on Blood Safety. The national data are presented in 12 annexes which detail for each nation the numbers of blood centers, of whole blood donations from VBD, RBD and paid donors, and of apheresis donations, methods and coverage of TTI screening, prevalence of TTI markers, numbers of blood components prepared and transfused, and indicators of policy, governance and quality assurance. The IBCO data from the PAHO report on the Supply of Blood for Transfusion in Latin American and Caribbean Countries 2012-2013, ${ }^{17}$ published in 2015, are part of the Global Database and are usually included in the WHO Global Reports. Post-2013 national information for IBCO was obtained from a 2017 report on blood supply for the Americas, ${ }^{18}$ while that for specific blood services was provided by IBCO national health authorities, as indicated in each corresponding table. ${ }^{19-21}$

\section{Lessons}

\section{National Requirements For Blood Components Are Determined Locally And Cannot Be Estimated Using Generic Global Indicators}

Accurate estimates of patient needs are essential if blood services are to provide sufficient components for all who need transfusions ${ }^{22}$ and to achieve the goal of universal access to blood. ${ }^{23}$ Indicators that have been proposed for estimating yearly requirements at the national level include (a) $1-5 \%$ of the population, ${ }^{23-25}$ (b) the number of hospital beds multiplied by $5-15^{26}$ and (c) 0.40 units/ patient admitted to hospitals. ${ }^{27}$ Recently, the Lancet 
Commission on Global Surgery recommended that countries collect at least 15 units/1000 population in order to provide adequate surgical care. ${ }^{28}$

In 2013, IBCO had 600,304,000 inhabitants and 1,211,353 hospital beds. Based on an annual collection rate equal to $3 \%$ of the population - considered sufficient by WHO to cover all needs - the estimated requirement was $18,009,120$ units, equivalent to $226 \%$ of the actual documented collection of $8,337,141$ units. The latter figure is $98 \%$ of the estimate that would be obtained by multiplying the number of hospital beds by seven, or $8,479,471$. The similarity between these two numbers suggests that estimates based on hospital beds might be sufficiently accurate to guide annual collection. Examining the individual country donation rates proves this conclusion incorrect: national collection rates based on units/hospital bed were 4.44-13.92 (median=9.61), and only three countries collected 7 units/bed/year; those with collection rates below $7 /$ bed discarded $10-33 \%$ of their red blood cells (RBC), suggesting that hospitals beds do not provide a valid criterion to either estimating needs or assessing sufficiency of blood for transfusion in IBCO.

Table 1 lists IBCO according to their Human Health Index (HHI, range 0.727-0.992, median 0.843), which is a composite of life expectancy at birth ${ }^{29}$ and provides more meaningful context for health issues than national income. Blood collection rates are expressed as units/10,000 inhabitants. According to this indicator (range 66.52-365.52, median 129.35), Cuba collected 5.5 times more blood than Peru, three countries had rates above 200 , and four had rates below 100. Units collected/physician ranged from 5.20 to 22.42 (median 7.45). The numbers of blood units collected/hospital bed were independent of HHI $\left(r_{\mathrm{s}}=-0.294, p=0.221193\right)$, numbers of units/physician were inversely correlated with HHI $\left(\mathrm{r}_{\mathrm{s}}=-0.594, p=0.009411\right)$ and collections per 10,000 inhabitants were directly correlated with $\mathrm{HHI}\left(\mathrm{r}_{\mathrm{s}}=0.4609, p=\right.$ 0.04751 ). The proportions of RBC discarded (range 4.10 33.25, median 14.66) did not correlate with units collected/ population $\left(\mathrm{r}_{\mathrm{s}}=-0.2179, p=0.3866\right)$, indicating that $\mathrm{RBC}$ disposal was not due to excessive collection by those countries with more blood available. Six countries, including two with collection rates below $100 / 10,000$ population, discarded more than $20 \%$ of their RBC. The national rates of $\mathrm{RBC}$ used/10,000 population (range 52.26-350.53, median 110.41) not only correlated more strongly with HHI $\left(r_{s}=0.4917, p=0.03238\right)$ than the corresponding collection rates but also demonstrated that only two countries utilized more than 200 units/10,000 inhabitants and eight used less than 100 .

In order to estimate blood needs, it is important to understand how blood is used in clinical settings. In Guatemala, two national high-complexity reference hospitals in the capital city transfused 40 and 72 units/1000 admissions, respectively; eight regional reference hospitals transfused $8-51 ; 16$ provincial hospitals used 7-40; and two district hospitals transfused 13 and 16 units/1000 patients. ${ }^{15}$ Overall, in Guatemala's 33 national hospitals, $45 \%$ of all patients were cared for at the emergency wards. Wide variations, up to five-fold, were seen in the annual use of RBC among hospitals of the same level of complexity when admissions and emergencies combined were used as the denominator. ${ }^{15}$

Observations in Nicaragua ${ }^{30}$ showed significant monthly variations in hospital admissions, in the proportion of those who receive $\mathrm{RBC}$, and in the numbers of $\mathrm{RBC}$ units administered. In addition to the patients' clinical condition, doctors' decisions to admit and/or transfuse patients were also influenced by factors such as distance, travel time and expenses involved in reaching the hospital, and the potential of losing patients to follow-up, indicating that the application of pertinent locally developed transfusion guidelines facilitates more reliable estimation of blood needs.

\section{The Development Of Blood Services Depends On The General Development Of The National Health System}

In the Region of the Americas, the national availability of blood for transfusions, expressed as units/10,000 population, is inversely correlated with national maternal mortality ratios (MMR). ${ }^{31}$ National rates of $\mathrm{RBC}$ use/10,000 population correlate directly with $\mathrm{HHI}$ ( $\mathrm{rs}=0.4917, p=0.032384$ ), and higher utilization of $\mathrm{RBC}$ is associated with lower MMR and infant mortality rates $^{15}$ (IMR). There is a direct correlation between MMR and IMR $\left(\mathrm{r}_{\mathrm{s}}=0.8064, p=0.000093\right)$. National rates of blood collection per physician are directly correlated with both national MMR (range: 16.0-229.0, median 61.6; $\mathrm{r}_{\mathrm{s}}=0.5996, p=0.008479$ ) and IMR (range: 4.2-24.8; median 14.6; $\mathrm{r}_{\mathrm{s}}=0.6118, p=0.011874$ ), suggesting that the higher collection rates reflect shortages of physicians in deficient health care facilities rather than augmented blood collection. This would explain why transfusion rates in IBCO tend to be lower in those countries with less access to renal and liver 
Table I Blood Collection And Use In Ibero-American Countries, 2013

\begin{tabular}{|c|c|c|c|c|c|c|c|}
\hline \multirow[t]{2}{*}{ Country } & \multirow[t]{2}{*}{ HHI } & \multicolumn{4}{|c|}{ Annual Blood Collection } & \multirow{2}{*}{$\begin{array}{l}\text { Rate Of RBC } \\
\text { Discard (\%) }\end{array}$} & \multirow{2}{*}{$\begin{array}{l}\text { Rate Of RBC } \\
\text { Use// 0,000 }\end{array}$} \\
\hline & & Number & Rate/ I 0,000 & Rate/Bed & Rate/Physician & & \\
\hline Costa Rica & 0.992 & 68,209 & 138.13 & 12.56 & 5.50 & 21.55 & 108.36 \\
\hline Chile & 0.992 & 229,911 & 129.35 & 5.88 & 7.11 & 9.95 & 116.48 \\
\hline Cuba & 0.912 & $4 \mid I, 545$ & 365.52 & 7.17 & 5.22 & 4.10 & 350.53 \\
\hline Panama & 0.885 & 53,529 & 136.34 & 5.93 & 8.58 & 14.97 & 115.93 \\
\hline Mexico & 0.885 & $1,364,395$ & 110.21 & 7.35 & 5.20 & 14.88 & 93.81 \\
\hline Uruguay & 0.880 & 99,151 & 290.00 & 11.60 & 6.17 & 9.08 & 263.73 \\
\hline Ecuador & 0.869 & 229,018 & 143.20 & 9.61 & 9.02 & 9.38 & 129.04 \\
\hline Argentina & 0.866 & 966,059 & 231.10 & 4.72 & 6.08 & 33.25 & 154.26 \\
\hline Nicaragua & 0.844 & 72,658 & 118.74 & 13.92 & 14.13 & 4.23 & 113.72 \\
\hline Peru & 0.843 & 204,87 I & 66.52 & 4.44 & 6.55 & 21.43 & 52.26 \\
\hline Venezuela & 0.841 & 340,345 & 110.32 & 12.26 & & 10.33 & 98.92 \\
\hline Colombia & 0.831 & 740,173 & 151.27 & 10.08 & 9.00 & 14.66 & 129.05 \\
\hline Brazil & 0.830 & $2,969,204$ & 146.97 & 6.39 & 9.69 & 24.87 & $|10.4|$ \\
\hline Honduras & 0.828 & 69,082 & 83.62 & 11.94 & 9.95 & 16.92 & 69.49 \\
\hline Dominican Republic & 0.822 & 110,780 & 105.21 & 6.58 & 6.88 & 8.89 & 95.86 \\
\hline El Salvador & 0.809 & 98,088 & 153.65 & 13.97 & 6.68 & 10.70 & 137.24 \\
\hline Paraguay & 0.804 & 86,056 & 126.20 & 9.70 & 7.79 & 28.14 & 90.68 \\
\hline Guatemala & 0.802 & $|2|, 92 \mid$ & 78.87 & $|2.8|$ & 10.38 & 25.29 & 58.92 \\
\hline Bolivia & 0.727 & 102,146 & 94.16 & 8.56 & 22.42 & 12.72 & 82.12 \\
\hline
\end{tabular}

Notes: Adapted with permission from Cruz JR. Satisfacción de los requerimientos de hemocomponentes [Satisfaction of the requirements for blood components]. In: Cortes-Buelvas A, Cabezas-Belalcazar AC, García-Castro Gutiérrez M, Urcelay-Uranga S, editors. Promoción de la donación voluntaria de sangre en Iberoamérica. Cali, GCIAMT. 20I7:6I-70. ${ }^{15}$ Data obtained from these studies. ${ }^{16,17} \quad$ : Not available. HHI/Collection rate per 10,000 correlation: $r_{s}=0.4609, p=0.0475 \mathrm{I}$. HHI/ collection rate per physician correlation: $r_{s}=-0.5940, p=0.0094 \mathrm{II}$. HHI/RBC use rate correlation: $r_{s}=0.4917, p=0.003238$.

Abbreviations: HHI, Human Health Index; RBC, red blood cells.

transplants and with lower numbers of diagnosed cases of hemophilia. ${ }^{15}$ In Guatemala, intra-hospital maternal deaths associated with bleeding commonly occur during weekends and national holidays, and in high-risk remote areas (Table 2). During working days, deaths are more likely to occur between $11 \mathrm{pm}$ and $5 \mathrm{am}$. In Bolivia, mothers with delivery complications did not have access to blood units stored in the hospitals because they were deposited for specific patients as a requisite for elective surgery (aka, replacement donation). ${ }^{32}$ This phenomenon results not only in poor patient management but also inefficient use of dedicatedly stocked blood. In two consecutive years, 131 mothers died due to peripartum hemorrhage in 32 Guatemalan hospitals where 6401
RBC units, or 49 units per deceased woman, were discarded during the same period. ${ }^{19,20}$ Focusing on patient transfusion needs and patient outcomes is necessary for implementing adequate national blood collection, processing and distribution processes.

\section{More Blood Banks Do Not Result In Better Availability Or Access To Blood Components}

In 2015, there were 2254 blood processing centers in IBCO ${ }^{18}$ Fifteen countries had fewer than 100 such centers while the four nations with federal-type government -Argentina, Venezuela, Brazil and Mexico-had 259, 339, 530 and 572 centers, respectively (Table 3), a 
Table 2 Maternal Deaths Due To Hemorrhage In Public Hospitals Of Guatemala, 2015-2016

\begin{tabular}{|l|l|l|l|l|l|}
\hline Type Of Hospital & $\begin{array}{l}\text { Number Of Hospitals } \\
\text { With Deaths }\end{array}$ & Number Of Deaths & \multicolumn{2}{l|}{$\begin{array}{l}\text { Deaths On Weekends And } \\
\text { Holidays }\end{array}$} & $\begin{array}{l}\text { Number Of RBC } \\
\text { Units Discarded }\end{array}$ \\
\cline { 3 - 6 } & & & Number & Proportion \\
\hline National reference & 2 & 20 & 4 & $20 \%$ & 2482 \\
Regional & 8 & 52 & 25 & $48 \%$ & 1769 \\
Provincial & 9 & 41 & 18 & $44 \%$ & 1935 \\
District, Contingency, Health Center & 13 & 18 & 12 & $67 \%$ & 215 \\
Total & 32 & 131 & 59 & $45 \%$ & 6401 \\
\hline
\end{tabular}

Note: Data obtained from these studies. ${ }^{19,20}$

Abbreviation: RBC, red blood cells.

result of the blood services being set up and managed by each autonomous state/province. The mean number of blood units processed annually per center in each country varied from 884 to 37,477 (median 4478, Table 3). Given that smaller centers are more prone to producing inaccurate laboratory testing results ${ }^{33,34}$ and to being financially inefficient, ${ }^{35}$ assessing the availability of blood and the operational efficacy of such processing systems is important. Using the number of blood processing centers $/ 100,000$ inhabitants as an indicator, it becomes clear that countries with blood center density indexes (BCDI) higher than the median process fewer units per center, have lower proportions of VBD, defer more prospective donors, have higher prevalence of TTI markers, prepare fewer components per unit, and discard more RBC due to expiry as compared to countries with indexes lower than the median (Table 3, $\mathrm{Chi}^{2}=14.93, p<0.0001$ ). The BCDI show no correlation with national rates of $\mathrm{RBC}$ use $\left(\mathrm{r}_{\mathrm{s}}=0.0754, p=0.760329\right)$, indicating that more blood processing centers do not result in increased availability of or access to blood components.

In Guatemala, just five of the existing 60 blood centers processed $42 \%$ of all the units collected in the country (Table 4). ${ }^{20}$ In Honduras, the three blood centers managed by the Red Cross accounted for $50 \%$ of national blood collection in 2018. Processes and operational results differed among the three Honduran centers (Table 5), a finding that led to closure of the smallest center in $2019 .{ }^{21}$

These data, and the impact of reducing the processing centers from 37 to two in Nicaragua, ${ }^{14}$ demonstrate that planning and implementing national blood systems with the suitable number of centers can result in optimum availability of blood components and efficient use of national resources, including blood.

\section{Regular Voluntary Donation Is A Major Contributor To Transfusion Safety}

During 2015, there were 4.9 million VBD and 6.7 million RBD in IBCO. ${ }^{18}$ The respective deferral rates were $15.5 \%$ and $24.4 \%$, amounting to 2.4 million individuals. Limitedscope observations point to low hemoglobin and risk behaviors for infectious disease transmission as major causes of deferral in both VBD and RBD. Unjustified deferral reasons include lipemic plasma, inappropriate veins, recent food intake, menstruation and over-stocked blood type. ${ }^{35,36}$ Despite these common factors, VBD were deferred in lower proportions (range: 4.63-23.57; median: 17.98) than RBD (Range: 7.97-33.01; Median 23.29). Lower deferral rates translate into more blood available and more efficient use of the resources to register and screen donors. With the pre-donation interview lasting $15 \mathrm{mins}$, the $2,380,501$ deferrals represent 316.5 full-time employees. The $57 \%$ excess associated with RBD compared to VBD equals 124 fulltime jobs. Once allowed to donate, VBD, especially those who have donated before, are less likely to have adverse reactions to donation ${ }^{37-40}$ and markers for TTI. ${ }^{41,42}$ The attributable monetary loss of 323,013 TTI-reactive donations in 2015 is US\$40.85 million.

Blood components derived from units that are not deposited for specific patients are available to any person in need of a transfusion. RBD not only limits access to available blood but also deters VBD, as the public is inclined to save their blood for family members or friends who may call on them as RBD. ${ }^{11}$ Eliminating the requirement for blood replacement is the most important intervention to achieve universal VBD, as has been shown in Nicaragua and Buenos Aires. ${ }^{12,14}$

In 2008, PAHO recommended that blood systems managers educate regular blood donors and to have them donate twice a year ${ }^{43}$ The purpose of the education 
Table 3 Operational Indicators Of Blood Centers, Ibero-American Countries, 2015

\begin{tabular}{|c|c|c|c|c|c|c|c|c|}
\hline \multirow[t]{2}{*}{ Country } & \multicolumn{2}{|c|}{$\begin{array}{l}\text { Blood Processing } \\
\text { Centers }\end{array}$} & \multicolumn{3}{|l|}{ Donors } & \multirow[t]{2}{*}{$\begin{array}{l}\text { Viral TTI } \\
\text { Markers }\end{array}$} & \multirow[t]{2}{*}{$\begin{array}{l}\text { Separation } \\
\text { Index }\end{array}$} & \multirow[t]{2}{*}{$\begin{array}{l}\text { RBC } \\
\text { Expiry }\end{array}$} \\
\hline & Number & $\begin{array}{l}\text { Densityl } \\
100,000\end{array}$ & $\begin{array}{l}\text { Per } \\
\text { Center }\end{array}$ & Voluntary & Deferred & & & \\
\hline Nicaragua & 2 & 0.0320 & 37,477 & 100 & 9.0 & 0.61 & 2.12 & 2.18 \\
\hline Paraguay & 6 & 0.0853 & 14,353 & 10.2 & 7.7 & 0.93 & 2.50 & 15.48 \\
\hline Chile & 17 & 0.0948 & $|4,09|$ & 28.5 & 22.3 & $0.06^{\mathrm{a}}$ & 2.62 & 7.18 \\
\hline Ecuador & 22 & 0.1365 & 11,222 & 68.3 & 15.7 & 0.85 & 2.40 & 6.21 \\
\hline Bolivia & 18 & 0.1633 & 6007 & 40.9 & 29.4 & 0.85 & 2.43 & 9.00 \\
\hline Colombia & 83 & 0.1675 & 9588 & 91.1 & 18.0 & 0.70 & 2.35 & 7.50 \\
\hline Honduras & 19 & 0.1899 & 4478 & 18.6 & 15.7 & 0.65 & 1.83 & 9.78 \\
\hline El Salvador & 13 & 0.2013 & 7145 & 17.0 & 25.0 & 0.35 & 2.72 & 7.74 \\
\hline Brazil & 530 & 0.2602 & 5848 & 61.3 & 19.3 & 0.77 & 2.30 & I7.I \\
\hline Peru & 89 & 0.2856 & 2302 & 4.6 & 29.7 & 1.17 & 2.32 & 13.03 \\
\hline Guatemala & 60 & 0.3691 & 2104 & 5.4 & 25.9 & 1.16 & 1.82 & 12.16 \\
\hline Cuba & 46 & 0.4089 & 9064 & 100 & 4.6 & 1.78 & 1.53 & 10.96 \\
\hline Mexico & 572 & 0.4567 & 3794 & 3.8 & 28.5 & 0.87 & 2.27 & 9.02 \\
\hline Panama & 22 & 0.5517 & 2560 & 7.0 & 23.0 & 0.73 & 2.09 & 14.75 \\
\hline Argentina & 259 & 0.6143 & 3965 & 45.7 & 14.2 & 1.06 & 2.20 & 7.30 \\
\hline Costa Rica & 32 & 0.6397 & 2367 & 60.4 & 22.5 & 0.45 & 2.83 & 14.35 \\
\hline Dominican Republic & 71 & 0.6665 & 1106 & 11.2 & 23.0 & 1.27 & 0.57 & 15.37 \\
\hline Venezuela & 339 & 1.0833 & 884 & 5.8 & 19.6 & 0.98 & 2.36 & 12.07 \\
\hline Uruguay & 54 & 1.5743 & 1679 & 51.4 & 23.4 & 0.53 & 1.90 & 20.56 \\
\hline
\end{tabular}

Notes: aConfirmed testing results. ${ }^{16}$ "Poor outcomes" in relation to the median values are shaded. ${ }^{29}$

Abbreviations: TTI, transfusion-transmissible infections; RBC, red blood cells.

Table 4 Blood Processing In Guatemala, 2016

\begin{tabular}{|l|l|l|l|l|l|}
\hline \multirow{2}{*}{ Institution } & \multicolumn{2}{l|}{ Larger Centers } & \multicolumn{2}{l|}{ Smaller Centers } & Institutional Mean \\
\cline { 2 - 5 } & Number & Total Units & Number & Total Units & \\
\cline { 2 - 5 } & 2 & $30,089(34 \%)$ & 31 & $57,353(66 \%)$ & 2650 \\
Sinistry of Health & 2 & $17,560(67 \%)$ & 3 & $8552(33 \%)$ & 5224 \\
Private sector & 1 & $7636(41 \%)$ & 21 & $10,970(58 \%)$ & 846 \\
All & 5 & $55,285(42 \%)$ & 55 & $76,875(58 \%)$ & \\
Annual mean & & 11,057 & & 1398 & 2203 \\
\hline
\end{tabular}

Note: Data obtained from this study. ${ }^{20}$

process should be to provide the individuals with the capacity and competences to decide to become blood donors, to protect their health, to understand why their blood donations are important for society, and to donate blood repeatedly. ${ }^{43}$ Limiting regular donations to two annually allows groups of females and males to donate together, reduces the risk of draining hemoglobin to unacceptable levels in repeat donors, and facilitates 
Table 5 Blood Collection And Processing, Honduran Red Cross National Program, 2018

\begin{tabular}{|l|l|l|l|l|l|l|}
\hline \multirow{2}{*}{ Blood Center } & \multicolumn{2}{|l|}{ Donors } & \multicolumn{2}{l|}{ Units } & \multirow{2}{*}{ Separation INDEX } & \multirow{2}{*}{ RBC Expiry } \\
\cline { 2 - 5 } & Voluntary & Deferred & Collected & TTI Markers & & \\
\hline CENASA & $6446(34 \%)$ & $2436(I 1 \%)$ & 18,837 & $44 I(2.34 \%)$ & 2.34 & $338(1.84 \%)$ \\
CERESA & $4969(23 \%)$ & $3622(15 \%)$ & 21,175 & $861(4.07 \%)$ & 2.40 & $66(0.32 \%)$ \\
CESAAT & 0 & $1255(22 \%)$ & 4489 & $229(5.1 \%)$ & 1.79 & 0 \\
All & $11,415(26 \%)$ & $7313(14 \%)$ & 44,501 & $1531(3.44 \%)$ & 2.31 & $404(0.94 \%)$ \\
\hline
\end{tabular}

Note: Data obtained from this study. ${ }^{21}$

programming extramural collections. Additionally, should unforeseen circumstances suddenly deplete the RBC stock, there would be enough eligible regular donors to replenish it. The initiative "Pledge 2 save lives" was created with those considerations in mind. ${ }^{43}$

\section{National Blood Systems Based On Consolidated, Stand-Alone Blood Processing Centers Which Focus On Serving Blood Donors And Satisfying Patient Needs Are More Effective And Contribute To Public Health}

Considering that blood components for transfusion are essential medicines and prepared locally using biological materials obtained from multiple individuals, PAHO proposed that consolidated processing facilities be responsible for distributing sufficient blood components to predetermined hospitals. ${ }^{42}$ Fewer processing centers are easier to oversee and make it easier to standardize operating procedures, implement quality assurance, hire specialized personnel, purchase and maintain equipment, procure consumables, acquire automated technology, manage donor and product information, reduce inequity in access to blood, and interact with public health and plasma fractionation institutions. ${ }^{33-35}$

The lessons described above are likely applicable in other parts of the world.

In 2013, 53 low- and lower-middle-income countries (LLMC) - 41 AFCO, 8 SECO and 4 IBCO - collected only $24 \%$ of the global blood supply and discarded the highest proportion of RBC among all income groups. ${ }^{16}$ These nations often fail to provide adequate, equitable, consistent, safe and timely blood supplies to their populations. ${ }^{44,45}$ Lack of government oversight, inadequate resources and fragmented national systems are some of the factors identified as responsible for poor access to safe blood, ${ }^{46,47}$ which in turn leads to poor patient outcomes. ${ }^{48,49}$ Recognizing regional heterogeneities, ${ }^{50}$ identifying gaps within each country, focusing attention at the local levels, and using successful experiences as models ${ }^{51-54}$ have been suggested as the basis for improving transfusion safety in LLMC. Table 6 summarizes the major health indicators for the three geographically distinct groups of countries. HHI $(p \leq 0.0023)$ is highest in IBCO, while both MMR and IMR are highest $(p<0.0001)$ in AFCO. All values for SECO are intermediate. The general main causes of death are infectious in AFCO, a mix of infectious and non-infectious in SECO, and non-infectious, including violence and road accidents, in IBCO. Understanding that the level of development of blood services depends on the general development of the health systems, it is not surprising that blood collection rates are lowest in AFCO, intermediate in SECO and highest in IBCO ( $p=0.0668$ ); the prevalence of viral TTI markers among donors follows the reverse pattern $(p \leq 0.0588$, Table 6$)$.

Table 7 shows HHI, main causes of death, MMR, IMR, proportion of births attended by skilled personnel, blood collection rates, and the estimated RBC transfusion rates in SECO. Maldives, Thailand, and Sri Lanka have the highest $\mathrm{HHI}$ and are also countries with upper-middle income. The Democratic Republic of Korea and Nepal, with low income, fall in the middle of the table. HHI is inversely correlated with both MMR ( $p=0.008516)$ and $\operatorname{IMR}(p=0.000145)$, confirming that HHI is a more valid reference for health issues than national income. IMR is inversely correlated with skilled attendance at birth ( $p=000544)$, and IMR and MMR are positively correlated ( $p=0.000672$ ), indicating that the level of health care determines both MMR and IMR and affects neonatal preterm mortality. "Poor outcomes" by all measures, including blood collection rates, are more likely to occur in countries with lower HHI. These rates seem to be lower than expected in at least five countries and in agreement with the assessment that SECO have an $11 \%$ deficit of blood based on the distribution of the global population. ${ }^{16}$ Reliable RBC transfusion rates could not be estimated for all countries. 
Table 6 Major Health Indicators Of Ibero-American, African And South-East Asian Countries, 2013

\begin{tabular}{|c|c|c|c|c|c|c|c|c|}
\hline \multirow[t]{2}{*}{ Countries } & \multirow{2}{*}{$\begin{array}{l}\text { Main causes of } \\
\text { death }\end{array}$} & \multicolumn{7}{|l|}{ Indicator } \\
\hline & & Measure & HHI & $\begin{array}{l}\text { Maternal } \\
\text { Mortality } \\
\text { Ratio }\end{array}$ & $\begin{array}{l}\text { Infant } \\
\text { Mortality } \\
\text { Rate }\end{array}$ & $\begin{array}{l}\text { Blood } \\
\text { Collection/ } \\
10,000\end{array}$ & $\begin{array}{l}\text { Viral TTI } \\
\text { Makers (\%) }\end{array}$ & $\begin{array}{l}\text { RBC } \\
\text { Usel } \\
10,000\end{array}$ \\
\hline \multirow[t]{2}{*}{ African } & \multirow{2}{*}{$\begin{array}{l}\text { LRI, malaria, HIV, } \\
\text { diarrhea }\end{array}$} & Median & 0.597 & 492 & 48.5 & 50.64 & 7.800 & 49.79 \\
\hline & & Range & $\begin{array}{l}0.393 \\
0.848\end{array}$ & $\begin{array}{l}42 \\
1360\end{array}$ & $\begin{array}{l}12 \\
96\end{array}$ & $\begin{array}{l}2.44 \\
391.66\end{array}$ & $\begin{array}{l}0.35 \\
22.62\end{array}$ & $\begin{array}{l}3.18 \\
369.36\end{array}$ \\
\hline \multirow[t]{2}{*}{ South-East Asian } & \multirow{2}{*}{$\begin{array}{l}\text { IHD, stroke, } \\
\text { neonatal conditions, } \\
\text { LRI }\end{array}$} & Median & 0.769 & 166 & 30 & 90.79 & 0.980 & 86.17 \\
\hline & & Range & $\begin{array}{l}0.695 \\
0.891\end{array}$ & $\begin{array}{l}21 \\
291\end{array}$ & $\begin{array}{l}9 \\
47\end{array}$ & $\begin{array}{l}18.82 \\
184.99\end{array}$ & $\begin{array}{l}0.32 \\
6.82\end{array}$ & $\begin{array}{l}16.89 \\
180.05\end{array}$ \\
\hline \multirow[t]{2}{*}{ Ibero-American } & \multirow{2}{*}{$\begin{array}{l}\text { IHD, violence, } \\
\text { stroke, road } \\
\text { accidents }\end{array}$} & Median & 0.843 & 66.6 & 14.6 & 129.35 & 0.835 & 110.40 \\
\hline & & Range & $\begin{array}{l}0.727 \\
0.992\end{array}$ & $\begin{array}{l}16 \\
229\end{array}$ & $\begin{array}{l}4.2 \\
24.8\end{array}$ & $\begin{array}{l}66.52 \\
365.52\end{array}$ & $\begin{array}{l}0.34 \\
1.82\end{array}$ & $\begin{array}{l}52.26 \\
350.53\end{array}$ \\
\hline
\end{tabular}

Abbreviations: HHI, Human Health Index; TTI, transfusion-transmissible infections; RBC, red blood cells; LRI, lower respiratory infections; IHD, ischemic heart disease.

Table 7 Human Health Index, Mortality, And Patient Care, South-East Asian Countries, 2013

\begin{tabular}{|c|c|c|c|c|c|c|c|}
\hline \multirow[t]{2}{*}{ Country } & \multirow[t]{2}{*}{ HHI } & \multicolumn{3}{|l|}{ Mortality } & \multicolumn{3}{|c|}{ Patient care } \\
\hline & & Main Causes & $\begin{array}{l}\text { Maternal } \\
\text { Mortality } \\
\text { Ratio }\end{array}$ & $\begin{array}{l}\text { Infant } \\
\text { Mortality } \\
\text { Rate }\end{array}$ & $\begin{array}{l}\text { Skilled- } \\
\text { Attended } \\
\text { Births }\end{array}$ & $\begin{array}{l}\text { Blood } \\
\text { Collection Ratel } \\
\text { I0,000 }\end{array}$ & $\begin{array}{l}\text { RBC } \\
\text { Transfusion } \\
\text { Rate/I0,000 }\end{array}$ \\
\hline Maldives & 0.891 & IHD, Congenital & 70 & 9 & 100 & 146.75 & $|4| .4 \mid$ \\
\hline Thailand & 0.837 & IHD, Stroke & 21 & 10 & 99 & 90.79 & 61.77 \\
\hline Sri Lanka & 0.835 & IHD, Self-harm & 32 & 9 & 100 & 184.99 & 180.05 \\
\hline Indonesia & 0.782 & Stroke, IHD & 140 & 25 & 93 & 108.03 & \\
\hline Bangladesh & 0.779 & Stroke, IHD & 201 & 33 & 50 & 37.68 & \\
\hline Dem Rep Korea & 0.769 & Stroke, IHD & 87 & 18 & 100 & 40.72 & 39.70 \\
\hline Nepal & 0.745 & LRI, IHD & 291 & 33 & 58 & 71.87 & \\
\hline Bhutan & 0.743 & NN preterm, IHD & 166 & 30 & 89 & 115.89 & 110.57 \\
\hline Timor Leste & 0.731 & LRI, NN preterm & 248 & 47 & 57 & 18.82 & 16.89 \\
\hline India & 0.714 & HID, NN preterm & 189 & 39 & 81 & 77.81 & \\
\hline Myanmar & 0.695 & Stroke, LRI & 189 & 44 & 60 & 51.81 & \\
\hline
\end{tabular}

Notes: "Poor outcomes" in relation to the median values are shaded. Not available. HHI/Maternal mortality ratio correlation: $r_{\mathrm{s}}=-0.697, p=0.0 \mathrm{I} 7032$. HHI/ Infant mortality rate correlation: $r_{s}=-0.8859, p=0.000283$. Maternal mortality ratio/Infant mortality rate correlation: $r_{s}=0.8604, p=0.000672$. Infant mortality rate/skilledattended births correlation: $r_{s}=-0.8664, p=0.000544$. HHI/collection rate correlation: $r_{s}=0.5364, p=0.04423$.

Abbreviations: HHI, Human Health Index; RBC, red blood cells; IHD, ischemic heart disease; NN, neonatal; LRI, lower respiratory infections.

Table 8 shows HHI, main causes of death, MMR, IMR, proportion of births attended by skilled personnel, blood collection rates, and the estimated RBC transfusion rates in AFCO. Cape Verde, Mauritius, and Seychelles, with HHI above 0.800, have low-medium, upper-medium and high income, respectively, and, together with upper-middle-income Algeria, show the lowest MMR and IMR of all 48 AFCO. There is no correlation between HHI and blood collection rates. The rate of RBC use correlates directly with HHI $(p=0.03108)$ and inversely with both MMR ( $p$ $=0.00031)$ and IMR $(p=0.00067)$, supporting the idea 
Table 8 Human Health Index, Mortality, And Patient Care, African Countries, 2013

\begin{tabular}{|c|c|c|c|c|c|c|c|}
\hline \multirow[t]{2}{*}{ Country } & \multirow[t]{2}{*}{ HHI } & \multicolumn{3}{|l|}{ Mortality } & \multicolumn{3}{|c|}{ Patient Care } \\
\hline & & Main Causes & $\begin{array}{l}\text { Maternal } \\
\text { Mortality } \\
\text { Ratio }\end{array}$ & $\begin{array}{l}\text { Infant } \\
\text { Mortality } \\
\text { Rate }\end{array}$ & $\begin{array}{l}\text { Skilled } \\
\text { Attended } \\
\text { Births }\end{array}$ & $\begin{array}{l}\text { Blood } \\
\text { Collection } \\
\text { Rate/l } 0,000\end{array}$ & $\begin{array}{l}\text { RBC } \\
\text { Transfusion } \\
\text { Rate/I } 0,000\end{array}$ \\
\hline Cape Verde & 0.848 & LRI, Stroke & 42 & 19 & 92.3 & 61.65 & 58.82 \\
\hline Mauritius & 0.825 & IHD, Diabetes & 53 & 13 & 99.8 & 391.66 & 369.36 \\
\hline Seychelles & 0.818 & IHD, LRI & 57 & 12 & 99.0 & 176.92 & 152.20 \\
\hline Algeria & 0.785 & IHD, NN preterm & 144 & 22 & & 125.43 & 109.69 \\
\hline Sao Tome \& Principe & 0.713 & LRI, NN sepsis & 156 & 29 & 92.5 & 48.11 & 41.72 \\
\hline Benin & 0.695 & Malaria, LRI & 405 & 69 & 77.2 & 75.36 & \\
\hline Madagascar & 0.688 & LRI, Diarrhea & 353 & 37 & 44.3 & 9.78 & \\
\hline Namibia & 0.684 & HIV, LRI & 265 & 37 & 88.2 & 118.74 & 112.02 \\
\hline Botswana & 0.683 & HIV, TB & 129 & 35 & 99.9 & 93.20 & 80.79 \\
\hline Rwanda & 0.678 & LRI, HIV & 290 & 35 & 90.7 & 37.96 & \\
\hline Ethiopia & 0.671 & LRI, Diarrhea & 353 & 48 & & 8.14 & \\
\hline Gabon & 0.669 & HIV, Malaria & 291 & 39 & & 99.19 & 74.49 \\
\hline Senegal & 0.668 & Diarrhea, LRI & 315 & & & 46.62 & \\
\hline Eritrea & 0.659 & Diarrhea, LRI & 501 & 36 & 34.1 & 16.61 & 14.74 \\
\hline Sudan & 0.647 & NN preterm, Congenital & 311 & 48 & & 50.20 & \\
\hline Kenya & 0.642 & HIV, Diarrhea & 510 & 37 & & 34.49 & \\
\hline United Republic of Tanzania & 0.639 & HIV, LRI & 398 & 44 & 48.9 & 31.33 & 25.48 \\
\hline Mauritania & 0.639 & LRI, NN sepsis & 602 & 58 & 65.1 & 26.79 & 24.20 \\
\hline Ghana & 0.633 & Malaria, LRI & 319 & 43 & & 58.45 & 49.79 \\
\hline Comoros & 0.629 & LRI, Diarrhea & 335 & 58 & 82.2 & 33.33 & 29.77 \\
\hline Liberia & 0.624 & LRI, Malaria & 225 & 63 & 61.1 & 60.60 & \\
\hline Zimbabwe & 0.613 & HIV, Diarrhea & 443 & 45 & 80.0 & 36.96 & 35.65 \\
\hline Uganda & 0.603 & HIV, LRI & 343 & 43 & & 52.26 & \\
\hline Congo & 0.597 & HIV, Malaria & 442 & 39 & 94.4 & 103.62 & 93.89 \\
\hline Gambia & 0.597 & LRI, NN sepsis & 706 & 45 & 57.2 & 52.46 & 51.09 \\
\hline Niger & 0.591 & Malaria, Diarrhea & 553 & 56 & 29.3 & 39.68 & 34.87 \\
\hline Zambia & 0.586 & HIV, LRI & 224 & 48 & 64.2 & 72.59 & 61.99 \\
\hline South Africa & 0.568 & HIV, Violence & 138 & 34 & 94.3 & 173.80 & 169.05 \\
\hline Togo & 0.562 & Malaria, HIV & 368 & & & 57.40 & \\
\hline Burkina Faso & 0.559 & Malaria, LRI & 371 & 58 & & 57.27 & 43.13 \\
\hline Guinea & 0.556 & Malaria, LRI & 679 & 64 & 45.3 & 35.34 & 28.81 \\
\hline
\end{tabular}


Table 8 (Continued).

\begin{tabular}{|c|c|c|c|c|c|c|c|}
\hline \multirow[t]{2}{*}{ Country } & \multirow[t]{2}{*}{ HHI } & \multicolumn{3}{|l|}{ Mortality } & \multicolumn{3}{|c|}{ Patient Care } \\
\hline & & Main Causes & $\begin{array}{l}\text { Maternal } \\
\text { Mortality } \\
\text { Ratio }\end{array}$ & $\begin{array}{l}\text { Infant } \\
\text { Mortality } \\
\text { Rate }\end{array}$ & $\begin{array}{l}\text { Skilled } \\
\text { Attended } \\
\text { Births }\end{array}$ & $\begin{array}{l}\text { Blood } \\
\text { Collection } \\
\text { Rate/I } 0,000\end{array}$ & $\begin{array}{l}\text { RBC } \\
\text { Transfusion } \\
\text { Rate/ } 10,000\end{array}$ \\
\hline Malawi & 0.543 & HIV, Malaria & 634 & 46 & & 34.52 & 18.30 \\
\hline South Sudan & 0.543 & Diarrhea, LRI & 789 & 63 & 17.2 & 2.44 & 3.18 \\
\hline Mali & 0.539 & Malaria, Diarrhea & 587 & 73 & 57.1 & 27.08 & 18.59 \\
\hline Somalia & 0.539 & Diarrhea, LRI & 712 & 89 & & 20.96 & \\
\hline Cameroon & 0.539 & HIV, Malaria & 596 & 62 & 64.7 & 20.50 & 17.68 \\
\hline Guinea Bissau & 0.528 & LRI, Diarrhea & 549 & 64 & 45.0 & 27.26 & 23.22 \\
\hline Burundi & 0.525 & LRI, Diarrhea & 712 & 51 & & 56.28 & 51.24 \\
\hline Nigeria & 0.500 & Malaria, Diarrhea & 814 & 73 & & 7.09 & \\
\hline Angola & 0.491 & LRI, Malaria & 477 & 64 & 46.7 & 57.32 & \\
\hline Chad & 0.480 & Diarrhea, LRI & 856 & 80 & 24.3 & 51.05 & 40.63 \\
\hline Cote D'lvoire & 0.473 & Malaria, HIV & 645 & 71 & & 59.039 & \\
\hline Mozambique & 0.465 & HIV, Malaria & 725 & 61 & 54.3 & 43.73 & \\
\hline Central African Republic & 0.464 & Malaria, HIV & 882 & 96 & & 35.30 & \\
\hline Democratic Rep of the Congo & 0.461 & Malaria, LRI & 693 & 78 & 80.1 & 59.042 & 50.01 \\
\hline Lesotho & 0.453 & HIV, Diarrhea & 487 & 72 & 77.9 & 37.24 & \\
\hline Eswatini & 0.446 & HIV, LRI & 389 & 49 & 88.3 & 106.20 & 93.43 \\
\hline Sierra Leone & 0.393 & Malaria, LRI & 1360 & 96 & 59.7 & 61.13 & 58.10 \\
\hline
\end{tabular}

Notes: "Poor outcomes" in relation to the median values are shaded. Not available. HHI/collection rate per population correlation: $r_{s}=0.2252$, $p=0.1232$. MMR/ IMR correlation: $r_{s}=0.8036, p<0.0000$ I. RBC use/MMR correlation: $r_{s}=-0.6044 p=0.0003 \mathrm{I}$. RBC use/IMR correlation: $r_{s}=-0.577, p=0.00067$. IM/Skilled-attended births correlation: $r_{s}=-0.5655, p=0.000735$. Skilled-attended births $/ R B C$ use correlation: $r_{s}=0.7723, p=0.000001$.

Abbreviations: HHI, Human Health Index; RBC, red blood cells; IHD, ischemic heart disease; NN, neonatal; LRI, lower respiratory infections.

that estimating national needs and assessing sufficiency of blood by using blood transfusion rates is more appropriate than using collection rates. Reliable data on RBC use were available for only 29 AFCO. Skilled attendance at birth correlates inversely with IMR ( $p$ $=0.000735$ ), and IMR and MMR are directly correlated ( $p$ $<0.000001)$. In general, "poor outcomes" on all measures are more likely to occur in the 24 countries with lower HHI ( $p$ $=0.0001$ ), corroborating that $\mathrm{HHI}$ segregates countries in a manner that facilitates understanding the relationships between national health services and local transfusion safety.

Table 9 shows operational indicators of blood centers in SECO, with a caveat: only 6 of the 11 countries included all their centers in their reports. The BCDI shown were calculated using the number of centers that exist in the country, while the mean blood collection by center was estimated based on the number of centers included in the WHO report. ${ }^{16}$ Taking into consideration that lower BCDI regularly result in more units processed by each center, in the case of SECO a better approximation to operational efficiency may be achieved by examining the number of units collected per center in the six countries with complete data. Sri Lanka and Thailand, with the largest number of units collected per center, have $100 \%$ VBD, have the lowest prevalence of TTI markers, and separate over $95 \%$ of their units into components. Maldives, with only two centers, processes all its units into components and shows the third lowest prevalence of TTI markers despite having only $29.54 \%$ VBD. Bangladesh, Timor Leste, and Bhutan reported the highest 
Table 9 Operational Indicators Of Blood Centers, South-East Asian Countries, 2013

\begin{tabular}{|c|c|c|c|c|c|c|c|}
\hline \multirow[t]{2}{*}{ Country } & \multicolumn{2}{|c|}{ Blood Centers } & \multicolumn{2}{|c|}{ Blood Collection } & \multirow{2}{*}{$\begin{array}{l}\text { Voluntary } \\
\text { Donation }\end{array}$} & \multirow{2}{*}{$\begin{array}{l}\text { Viral TTI } \\
\text { Markers }\end{array}$} & \multirow{2}{*}{$\begin{array}{l}\text { Whole Blood } \\
\text { Separation }\end{array}$} \\
\hline & Number & Density & N Units & Per Center & & & \\
\hline Indonesia & $375(321)^{\mathrm{a}}$ & 0.1448 & $2,722,758$ & 8482 & 84.72 & 2.110 & 60.4 \\
\hline India & $2760(2545)$ & 0.1990 & $9,949,012$ & 3909 & 85.00 & 1.600 & 60.0 \\
\hline Bangladesh & 327 & 0.2075 & 593,774 & 1816 & 29.64 & 0.976 & 18.7 \\
\hline Thailand & 170 & 0.2495 & 618,675 & 3639 & 100 & 0.480 & 96.4 \\
\hline Nepal & $100(86)$ & 0.3573 & 201,122 & 2339 & 87.79 & 0.570 & 25.6 \\
\hline Sri Lanka & 90 & 0.4272 & 380,808 & 4231 & 100 & 0.324 & 100 \\
\hline Maldives & 2 & 0.5038 & 5826 & 2913 & 29.54 & 0.920 & 100 \\
\hline Timor Leste & 6 & 0.5068 & 2227 & 372 & 33.15 & 6.820 & 74.7 \\
\hline Myanmar & $334(145)$ & 0.6491 & 266,540 & 1838 & 76.86 & 3.210 & 79.5 \\
\hline Dem Rep Korea & $188(12)$ & 0.7524 & 101,742 & 8479 & 100 & 0.920 & 70.0 \\
\hline Bhutan & 27 & 3.5340 & 8854 & 328 & 63.12 & 1.180 & 50.8 \\
\hline
\end{tabular}

Notes: ${ }^{a}$ Numbers of blood centers which provided information. "Poor outcomes" in relation to the median values are shaded.

Abbreviation: TTI, transfusion-transmissible infections.

TTI prevalence rates and the lowest separation of blood into components. Total RBC discard was estimated at $31.2 \%$ and, as a consequence, $68 \%$ of $\mathrm{RBC}$ collected were actually transfused. Implementing universal VBD in SECO would result in improved availability and safety of blood. Nevertheless, in order to better understand the status of transfusion safety in SECO, the first priority should be the systematic local collection, validation, and analysis of data from blood centers and hospitals. Regulation and inclusion of unbanked directed blood transfusion ${ }^{47}$ and unlicensed blood brokers ${ }^{49}$ require special attention by health authorities, since they may manage up to $25 \%$ of the blood transfused in SECO. ${ }^{51}$

Table 10 shows operational indicators of the blood centers in AFCO. The BCDI fluctuate between 0.0134 and 1.2072 (median 0.1173). The number of blood units processed/center annually varies from 489 in the Democratic Republic of Congo to 86,172 in South Africa. There are 7 AFCO with VBD below 20\%; 17 of them collect more than $90 \%$ of their units from VBD, with 9 having universal VBD. Prevalence rates of viral TTI markers vary from 0.35 in South Africa to 22.62 in Mali. Seychelles, Mauritius, Namibia, and Algeria report viral TTI prevalence under $1.00 ; 16$ countries find more than $10 \%$ of their donations reactive for viral TTI. Twenty-two countries prepare components from less than $50 \%$ of the units collected. Eighteen of 29 AFCO with data discard more than $10 \%$ of the RBC they prepare. It was estimated that $11.6 \%$ of the collected $\mathrm{RBC}$ were discarded and, as a consequence, $88 \%$ of the RBC collected during 2013 were transfused. Operational "poor outcomes" are more likely among the 24 AFCO with BCDI above the median $(p=0.0001)$. Eritrea, Namibia, Eswatini, Mauritius, Sao Tome and Principe, and Seychelles have only one blood center. Countries with two centers may want to keep them both as part of a contingency plan and because of the size of territory and transportation facilities. Independent of the BCDI, understanding where, when, and how many blood components are needed is essential to plan adequate blood collection, preparation and delivery to hospitals before patients' medical conditions indicate transfusions. A national plan to avoid excessive discard of RBC will result in considerable financial savings.

\section{Final Remarks}

Important lessons were learned from efforts to improve transfusion safety in IBCO during the last 25 years. Initial work focused on prevention of TTI. The systematic communication among national blood programs to assure valid data on TTI facilitated the establishment of a quality-controlled blood processing information system and solid 
Table 10 Operational Indicators Of Blood Centers, African Countries, 2013

\begin{tabular}{|c|c|c|c|c|c|c|c|c|}
\hline \multirow[t]{2}{*}{ Country } & \multicolumn{2}{|c|}{ Blood Centers } & \multicolumn{2}{|c|}{ Blood Collection } & \multirow{2}{*}{$\begin{array}{l}\text { Voluntary } \\
\text { Donation }\end{array}$} & \multirow{2}{*}{$\begin{array}{l}\text { Viral TTI } \\
\text { Markers }\end{array}$} & \multirow{2}{*}{$\begin{array}{l}\text { Whole Blood } \\
\text { Separation }\end{array}$} & \multirow{2}{*}{$\begin{array}{l}\text { Rate Of RBC } \\
\text { Discard (\%) }\end{array}$} \\
\hline & Number & Density & $\begin{array}{l}\mathbf{N} \\
\text { Units }\end{array}$ & $\begin{array}{l}\text { Per } \\
\text { Center }\end{array}$ & & & & \\
\hline Tanzania & 7 & 0.0134 & 163,645 & 23,378 & 84.59 & 6.22 & 23 & 18.67 \\
\hline South Sudan & 2 & 0.0173 & 2812 & 1406 & 2.31 & 19.91 & 0 & \\
\hline Eritrea & 1 & 0.0191 & 8692 & 8692 & 92.48 & 3.18 & 92.6 & 11.26 \\
\hline South Africa & 11 & 0.0202 & 947,890 & 86,172 & 99.96 & 0.35 & 99.7 & 2.73 \\
\hline Malawi & 4 & 0.0234 & 48,579 & 12,145 & 30.09 & 7.80 & 6.9 & 46.49 \\
\hline Nigeria & 43 & 0.0244 & $|25,10|$ & 2909 & 42.98 & 8.50 & & \\
\hline Ethiopia & 25 & 0.0257 & 79,274 & $317 \mid$ & 67.72 & 5.50 & 30.8 & \\
\hline Niger & 5 & 0.0261 & 75,977 & 15,195 & 33.91 & 12.28 & 1.6 & 12.12 \\
\hline Togo & 2 & 0.0277 & 41,488 & 20,774 & 95.35 & 5.35 & 66.4 & \\
\hline Zimbabwe & 5 & 0.0324 & 56,958 & 11,392 & 100 & 1.33 & 95.8 & 31.54 \\
\hline Uganda & 14 & 0.0360 & 202,935 & 14,495 & 100 & 3.64 & 60 & \\
\hline Namibia & 1 & 0.0422 & 28,143 & 28,143 & 100 & 0.89 & 99.8 & 5.66 \\
\hline Sierra Leone & 30 & 0.0423 & 43,273 & 1442 & 10.00 & 15.27 & 0 & 4.95 \\
\hline Rwanda & 5 & 0.0441 & 43,074 & 8615 & 100 & 3.30 & 100 & \\
\hline Central African Republic & 2 & 0.0443 & 11,423 & 5712 & 98.92 & 17.10 & & \\
\hline Sudan & 20 & 0.0529 & 189,432 & 9472 & 17.11 & 7.45 & & \\
\hline Mali & 9 & 0.0530 & 45,932 & 5104 & 30.60 & 22.62 & 55.9 & 31.35 \\
\hline Zambia & 9 & 0.0576 & 113,386 & 12,598 & 100 & 10.50 & 10.6 & 14.60 \\
\hline Burundi & 7 & 0.0708 & 55,666 & 7952 & 99.97 & 10.52 & 39.8 & 8.95 \\
\hline Eswatini & I & 0.0786 & 13,498 & 13,498 & 100 & 4.63 & & 12.02 \\
\hline Mauritius & 1 & 0.0794 & 49,349 & 49,349 & 84.36 & 0.40 & 49.9 & 5.69 \\
\hline Cote D'lvoire & 23 & 0.1021 & 133,023 & 5784 & 100 & 7.75 & 94.5 & \\
\hline Gabon & 2 & 0.1067 & 18,598 & 9299 & 68.30 & 6.41 & 97.3 & 24.90 \\
\hline Kenya & 54 & 0.1173 & 158,742 & 2940 & 100 & 2.32 & 60.7 & \\
\hline Senegal & 21 & 0.1444 & 67,815 & 3229 & 94.23 & 10.09 & 51.8 & \\
\hline Lesotho & 4 & 0.1864 & 7988 & 1997 & 96.62 & 4.95 & 43.4 & \\
\hline Madagascar & 47 & 0.1992 & 23,075 & 491 & 18.60 & 4.89 & 35.8 & \\
\hline Somalia & 31 & 0.2294 & 28,330 & 914 & 35.00 & 4.09 & 0 & \\
\hline Burkina Faso & 43 & 0.2445 & 100,716 & 2342 & 67.55 & 16.74 & 91.4 & 24.69 \\
\hline Cameroon & 55 & 0.2473 & 46,483 & 845 & 8.14 & 11.52 & 0 & 13.76 \\
\hline Botswana & 6 & 0.2767 & 20,207 & 3368 & 100 & 1.96 & 100 & $13.3 \mid$ \\
\hline Guinea Bissau & 5 & 0.2898 & 4703 & 941 & 28.79 & 18.94 & 0 & 14.82 \\
\hline
\end{tabular}

(Continued) 
Table 10 (Continued).

\begin{tabular}{|c|c|c|c|c|c|c|c|c|}
\hline \multirow[t]{2}{*}{ Country } & \multicolumn{2}{|c|}{ Blood Centers } & \multicolumn{2}{|c|}{ Blood Collection } & \multirow{2}{*}{$\begin{array}{l}\text { Voluntary } \\
\text { Donation }\end{array}$} & \multirow{2}{*}{$\begin{array}{l}\text { Viral TTI } \\
\text { Markers }\end{array}$} & \multirow{2}{*}{$\begin{array}{l}\text { Whole Blood } \\
\text { Separation }\end{array}$} & \multirow{2}{*}{$\begin{array}{l}\text { Rate Of RBC } \\
\text { Discard (\%) }\end{array}$} \\
\hline & Number & Density & $\begin{array}{l}\mathbf{N} \\
\text { Units }\end{array}$ & $\begin{array}{l}\text { Per } \\
\text { Center }\end{array}$ & & & & \\
\hline Mauritania & 13 & 0.3199 & 10,886 & 837 & 25.21 & 16.86 & 100 & 9.67 \\
\hline Guinea & 38 & 0.3219 & 41,718 & 1098 & 11.10 & 11.40 & 0.8 & 18.48 \\
\hline Mozambique & 153 & 0.3676 & 119,003 & 778 & 43.87 & 9.54 & 100 & \\
\hline Ghana & 103 & 0.3820 & 160,295 & 1556 & 33.00 & 11.50 & 16.6 & 14.82 \\
\hline Benin & 40 & 0.3889 & 77,510 & 1938 & 95.49 & 14.18 & & \\
\hline Chad & 56 & 0.4127 & 69,265 & 1237 & 6.22 & 15.15 & 1.9 & 20.46 \\
\hline Algeria & 200 & 0.5113 & 490,633 & 2453 & 31.28 & 0.54 & 92.4 & 15.55 \\
\hline Angola & 139 & 0.5163 & 154,300 & 1110 & 14.75 & 7.23 & 10.5 & \\
\hline Sao Tome \& Principe & 1 & 0.5236 & 919 & 919 & 65.29 & 12.96 & 75.0 & 13.28 \\
\hline Congo & 29 & 0.5954 & 50,472 & 1740 & 38.54 & 10.38 & 53.8 & 9.39 \\
\hline Gambia & 12 & 0.6260 & 10,057 & 838 & 21.50 & & 0 & \\
\hline Comoros & 5 & 0.6588 & 2530 & 506 & 11.46 & 5.14 & 0 & 10.68 \\
\hline Liberia & 40 & 0.9112 & 26,602 & 665 & 26.31 & & 0 & \\
\hline Seychelles & I & 1.0990 & 1610 & 1610 & 50.93 & 0.00 & I.I & 13.97 \\
\hline Cape Verde & 6 & I. 1407 & 3243 & 540 & 85.17 & 1.81 & 98.9 & 4.59 \\
\hline Democratic Rep of Congo & 890 & 1.2072 & 435,275 & 489 & 35.70 & 6.24 & 75.0 & 15.30 \\
\hline
\end{tabular}

Notes: "Poor outcomes" in relation to the median values are shaded. density > 0.13085; $\mathrm{Chi}^{2}=14.42, p=0.0001$.

Abbreviations: TTI, transfusion-transmissible infections; RBC, red blood cells.

collaboration among stakeholders. Delayed, deficient or lack of provision, however, called for securing timely access to blood by patients. The negative consequences of RBD as a requirement for patient treatment at hospitals became obvious. The pursuit of universal VBD was hindered by unawareness of time- and space-driven requirements for blood components at hospitals, and the preference among the public to save their blood for a relative potentially in need of RBD. Review of transfusion practices showed poor record keeping and variable patient management. It was understood that only hospital-based clinical guidelines provide a valid framework for estimating future patterns of blood needs. Blood donors were recognized as vital for achieving blood sufficiency and timely access to transfusions; therefore, nurturing donors became a central strategy. Recognizing that blood transfusion services are part of the national health system is indispensable for self-sufficiency and timely access to blood. The application of lessons learned in IBCO may allow countries of other parts of the world to improve their blood safety in the near future.

\section{Abbreviations}

AFCO, African countries; BCDI, blood center density index; HHI, Human Health Index; IBCO, Ibero-American countries; IMR, infant mortality rate; LLMC, low- and lowermiddle income countries; MMR, maternal mortality ratio; PAHO, Pan American Health Organization; RBC, red blood cells; RBD, REPLACEMENT blood donation; SECO, South-East Asian countries; TTI, transfusion-transmissible infections; VBD, voluntary blood donation; WHA, World Health Assembly; WHO, World Health Organization.

\section{Data Availability}

Pan American Health Organization. Supply of blood for transfusion in Latin American and Caribbean countries 
2012 and 2013. https://apps.who.int/iris/handle/10665/ 310766?show=ful. World Health Organization. 2016 Global Status Report on Blood Safety and Availability. https://apps.who.int/iris/bitstream/handle/10665/254987/ 9789241565431-eng.pdf?sequence=1. Pan American Health Organization. Supply of blood for transfusion in Latin American and Caribbean countries 2014 and 2015. https:// apps.who.int/iris/handle/10665/310766?show=ful.

\section{Acknowledgments}

The author acknowledges Ms. Donna Eberwine-Villagran for her editorial support.

\section{Funding}

The author did not receive any financial support from a third party and covered all expenses associated with the preparation of this manuscript.

\section{Disclosure}

The author was Regional Advisor on Laboratory and Blood Services (1994-2011) and Senior Advisor on Health Technologies for Quality of Care (2009-2011), Pan American Health Organization, Regional Office for the Americas, World Health Organization. He was also a member of AABB Global Standards Committee (2015-2017). He is an honorary member of Grupo Cooperativo IberoAmericano de Medicina Transfusional (GCIAMT, 2013present), a member of Education Committee of the African Society for Transfusion Medicine (2017-present). The author reports no other conflicts of interest in this work.

\section{References}

1. World Health Organization. Official records. No. 226. 28th World Health Assembly. Annex 14. Utilization and supply of human blood and blood products. A28/WP/6-1. Geneva, 1975.

2. Twenty-eighth World Health Assembly. Resolution WHA28.72. Utilization and supply of human blood and blood products. Geneva, 1975.

3. Fortieth World Health Assembly. Resolution WHA40.26. Global strategy for the prevention and control of AIDS. Geneva, 1987.

4. Forty-fifth World Health Assembly. Resolution WHA45.35. Global strategy for the prevention and control of AIDS. Geneva, 1992.

5. Fifty-third World Health Assembly. Resolution WHA53.14. HIV/ AIDS: confronting the epidemic. Geneva, 2000.

6. Fifty-sixth World Health Assembly. Resolution WHA56.30. Global health-sector strategy for HIV/AIDS. Geneva, 2003.

7. World Health Organization Regional Office for Africa Regional Committee: Forty-fourth session. Resolution AFR/RC44/R.12: AIDS control: current status of AIDS control activities in the African Region. 1994. doi:10.3168/jds.S0022-0302(94)77044-2

8. World Health Organization Regional Office for Africa Regional Committee: Fifty-fifth session. Resolution AFR.RC51/R2. Blood safety: a strategy for the African region. Brazzaville, 2001.
9. Pan American Health Organization. 41st Directing Council. Resolution CD41.R15. Strengthening blood banks in the Region of the Americas. San Juan, 1999. doi:10.1046/j.1469-1809.1999.6320101.x

10. World Health Organization. Universal access to safe blood transfusion. Scaling-up the implementation of the WHO strategy for blood safety and availability for improving patient health and saving lives. Geneva, 2007. doi:10.1094/PDIS-91-4-0467B

11. Pan American Health Organization. 46th Directing Council. Document CD46/16. Progress Report on the Global Safe Blood Initiative and Plan of Action for 2005-2010. Washington, DC, 2005.

12. Cruz JR, Berrios-Cruz R, Duque-Rodriguez J, Kuperman S. International collaboration for improving global blood safety and for monotring and responding to potential microbial threats. In: Shan H, Dodd RY, editors. Blood Safety. A Guide to Monitoring and Responding to Potential New Threats. Cham: Springer; 2019:225-249.

13. Grupo Cooperativo Iberoamericano de Medicina Transfusional. Estándares de Trabajo para Servicios de Sangre [Work Standards for Blood Services]. Primera Edición. Septiembre 2013. Spanish.

14. Berrios R, Gonzalez A, Cruz JR. Achieving self-sufficiency of red blood cells based on universal voluntary blood donation in Latin America. The case of Nicaragua. Transfus Apher Sci. 2013;49 (3):387-396. doi:10.1016/j.transci.2013.06.013

15. Cruz JR. Satisfacción de los requerimientos de hemocomponentes [Satisfaction of the requirements for blood components]. In: CortesBuelvas A, Cabezas-Belalcazar AC, García-Castro Gutiérrez M, Urcelay-Uranga S, editors. Promoción de la donación voluntaria de sangre en Iberoamérica. Cali: GCIAMT; 2017:61-70.

16. World Health Organization. 2016 global status report on blood safety and availability. Geneva, 2017.

17. Pan American Health Organization. Supply of blood for transfusion in Latin American and Caribbean countries 2012 and 2013. Washington, DC, 2015.

18. Pan American Health Organization. Supply of blood for transfusion in Latin American and Caribbean countries 2014 and 2015. Washington, DC, 2017.

19. Technical Group for Surveillance of Maternal Mortality. National Epidemiology Center. Cases of Maternal Death Due to Hemorrhage in the Health Services 2015, 2016. Guatemala, Guatemala: Ministry of Health and Social Assistance; 2018.

20. National Program of Transfusion Medicine and Blood Banks. Blood Data 2016. Guatemala, Guatemala: Ministry of Health and Social Assistance; 2017.

21. Honduran Red Cross. National Blood Program. Report of the National Blood Program, 2017, 2018. Comayaguela, Honduras, 2019

22. Sixty-third World Health Assembly. Availability, safety and quality of blood products. Document WHA63.20. Geneva, 2010.

23. World Health Organization. Safe blood and blood components. Module 1. Safe blood donation. Geneva, 1994. doi:10.3168/jds. S0022-0302(94)77044-2

24. Szilasky C. Calculation of present and projected blood needs. In: Holland SR, Wagstaff WW, Leikola J, Lothe F, editors. Management of Blood Transfusion Services. Geneva: World Health Organization; 1990:27-30.

25. World Health Organization. Universal access to safe blood transfusion. Geneva, 2008.

26. Gibbs WN, Britten AFH. Guidelines for the Organization of a Blood Transfusion Service. Geneva: World Health Organization; 1992.

27. Leikola J. How much blood for the world. Vox Sang. 1988;54(1):1-5. doi:10.1111/j.1423-0410.1988.tb01604.x

28. Meara JG, Leather AJM, Hagander L, et al; for The Lancet Commission. Global surgery 2030: evidence and solutions for achieving health, welfare, and economic development. Lancet. 2015;386(9993):569-624. doi:10.1016/S0140-6736(15)60160-X.

29. Human Development Reports [homepage on the internet]. New York: United Nations Development Programme; 2013. Available from: http://hdr.undp.org/en/content/health-index. Accessed June 5, 2019. 
30. Pan American Health Organization. Workshop on Validation of the Methodology. Managua, Nicaragua, December 2009. Presentations. In: Recommendations for Estimating the Need for Blood and Blood Components; 2010; Washington, DC.

31. Cruz JR. Reduction of maternal mortality: the need for voluntary blood donors. Int J Gynecol Obstet. 2007;98(3):291-293. doi:10.1016/j. ijgo.2007.01.020

32. Organización Panamericana de la Salud. Salud Materna en Bolivia: Análisis de la Respuesta del Sistema de Salud [Maternal Health in Bolivia: Analysis of the Response of the Health System]. Washington, DC; 2011.

33. Beltrán-Duran M, Ayala-Guzmán M. Evaluación externa de los resultados serológicos en los bancos de sangre de Colombia [External evaluation of serology results in blood Banks in Colombia]. Rev Panam Salud Pub. 2003;12(2/3):138-143. Spanish. doi:10.1590/ S1020-49892003000200015

34. Grijalva MJ, Chiriboga RF, Vanhassel H, Arcos-Teran L. Improving the safety of the blood supply in Ecuador through external performance evaluation of serological screening tests. J Clin Virol. 2005;34(Suppl 2):S47-S52.

35. Organización Panamericana de la Salud. Guía para la estimación de costos de la regionalización de los bancos de sangre [Guide for Estimating the Cost of Regionalizing Blood Banks]. Washington, DC; 2005. Spanish.

36. Llovet I, Dinardi G, Llovet D, Berenstein G. Cultura y organización en la donación de sangre. los casos de Argentina y Canada [Blood Donation Culture and Organization. The Cases of Argentina and Canada]. Buenos Aires, Argentina: Centro de Estudios de Estado y Sociedad; 2005. Spanish.

37. HM S-B, Bencomo-Hernandez A, Benet-Rodriguez CM, Lopez-Fernandez $\mathrm{R}$, Valls W, Ballster-Santovenia JM. La hemovigilancia de las reacciones adversas a la donacion [Hemovigilance of side effects of blood donation]. Rev Cubana Hematol Inmunol Hemoter. 2013;29(2):154-162. Spanish.

38. Goncalez TT, Sabino EC, Schlumpt KS, et al. Vasovagal reactions in whole blood donors at 3 REDS-II blood centers in Brazil. Transfusion. 2012;52(5):1070-1078. doi:10.1111/j.1537-2995.2011.03432.x

39. Munera MI, Ramírez BI. Reacciones adversas inmediatas a la donación: frecuencia y caracterización, Banco de Sangre de la Clínica Cardiovascular Santa María, Medellín [Immediate adverse reactions to blood donation: frequency and characterization, Santa Maria Cardiovascular Clinic Blood Bank, Medellin]. Biomédica. 2001;21:224-227. Spanish.

40. Chávez-Nieto C, Juárez-Barreto V, Lara-López E. Eventos adversos presentados durante la donación de sangre total [Adverse reactions to whole blood donation]. Resúmenes de Trabajos Libres del IX Congreso de la Asociación Mexicana de Medicina Transfusional, AC. Rev AMMT. 2011;4(2):117. Spanish.

41. Patino-Bedoya JA, Cortes-Marquez MM, Cardona-Arias JA Seroprevalence of markers of transfusion transmissible infections in blood bank in Colombia. Rev Saude Pub. 2012;46:6. doi:10.1590/ S0034-89102012000600004
42. Pan American Health Organization. 48th Directing Council, Document CD48/11. Improving blood availability and transfusion safety in the Americas. Washington, DC, 2008.

43. Pan American Health Organization. Eligibility for Blood Donation: Recommendations for Education and Selection of Prospective Blood Donors. Pledge 2 Save Lives. Give Blood Regularly. Washington, DC, 2009.

44. Kralievitz KE, Raykar NP, Greenberg SLM, Meara JG. The global blood supply: a literature review. Lancet. 2015;585(Suppl):S28. doi:10.1016/S0140-6736(15)60823-6

45. Custer B, Zou S, Glynn S, et al. Addressing gaps in international blood availability and transfusion safety in Low And Middle Income Countries (LMIC): a NHLBI workshop. Transfusion. 2018;58 (5):1307-1317. doi:10.1111/trf.14598

46. Bloch EM, Vermeulen M, Murphy E. Blood transfusion safety in Africa: a literature review of infectious disease and organizational challenges. Transf Med Rev. 2012;26(2):164-180. doi:10.1016/j. tmrv.2011.07.006

47. Jenny HE, Saluja S, Sood R, et al. Access to safe blood in lowincome and middle-income countries: lessons from India. $B M J$ Global Health. 2017;2:e000167. doi:10.11/bmjgh-2016-000167

48. Bates I, Chapotera GK, McKew S, van den Broek N. Maternal mortality in sub-Saharan Africa: the contribution of innefective blood transfusion services. BJOG. 2008;115:1331-1339. doi:10.1111/j.14710528.2008.01866.x

49. Akthter S, Anwar I, Akter, et al. Barriers to timely and safe blood transfusion for PPH patients: evidence from a qualitative study in Dhaka, Bangladesh. PLoS ONE. 2016;11(12):e0167399. doi:10.1371/ journal.pone.0167399

50. Loua A, Nikiema JB, Kasilo OMJ, Tagny CT. Blood safety and availability in the WHO African region. Glob Surg. 2018;4 (3): $1-7$.

51. Ramani KV, Mavalankar DV, Govil D. Study of blood-transfusion services in Maharashtra and Gujarat Sates, India. J Health Popul Nutr. 2009;27(2):259-270. doi:10.3329/jhpn.v27i2.3368

52. Aneke J, Okocha C. Blood transfusion safety: current status and challenges in Nigeria. Asian $J$ Transf Sci. 2017;11(1):1-5. doi:10.4103/0973-6247.200781

53. Loua A, Sonoo J, Musango L, Nikiema JB, Lapnet-Moustapha T. Blood safety status in WHO African region countries: lessons learnt from mautitius. J Blood Transf. 2017;2017:8. Article ID 1970479.

54. Kyeyune-Byabazaire D, Hume H. Towards a safe and sufficient blood supply in sub-Saharan Africa. ISBT Sci Ser. 2019;14:104113. doi:10.1111/voxs.2019.14.issue-1
International Journal of Clinical Transfusion Medicine

\section{Publish your work in this journal}

International Journal of Clinical Transfusion Medicine is an international, peer-reviewed, open access, online journal publishing clinical-experimental, policy-making and evidence-based practices of all topics pertaining to clinical transfusion medicine. Original research, short reports, reviews, case reports and commentaries are invited.
The manuscript management system is completely online and includes a very quick and fair peer-review system, which is all easy to use. Visit http://www.dovepress.com/testimonials.php to read real quotes from published authors.. 